\title{
THE GENERAL THEORY OF TAX AVOIDANCE ${ }^{1}$
}

\author{
JOSEPH E. STIGLITZ*
}

$\mathbf{T}$ T used to be said that there were two things that were unavoidable: death and taxes. There is a widespread feeling today that under our present tax code only one of these is unavoidable. What I wish to discuss today is why this is so, and how the extent of tax avoidance would be affected by some of the major tax reforms presently being discussed.

To do this, I shall first explain a general set of principles for tax avoidance, ${ }^{2}$ (Section I) and then present four methods of implementing these principles (Section II). In Section III, I discuss what determines the limits on the extent to which individuals can take advantage of tax avoidance schemes.

Many transactions, while they seem to reduce the tax liabilities to some parties to the transaction, increase those of others. Because "prices" (the terms of the transaction) adjust to reflect these changed tax liabilities, it is often difficult to ascertain who really benefits from many tax avoidance schemes. Moreover, the aggregate loss to the Treasury may be much less than the seeming gain to the alleged beneficiaries (when those calculations fail to take account of the general equilibrium effects of tax avoidance schemes). Thus, we follow our partial equilibrium analysis of tax avoidance (Sections I-III) with an analysis of some of the more important general equilibrium effects (Section IV). Some implications of our analysis for tax reform are provided in Section V.

\section{Principles of Tax Avoidance}

Tax laws constantly change the opportunities for tax avoidance, but underneath, there remain three basic principles of tax avoidance within an income tax: ${ }^{3}$

(1) Postponement of taxes. The present discounted value of a postponed tax is

*Princeton University. much less than that of a tax currently paid. ${ }^{4}$

(2) Tax arbitrage across individuals facing different tax brackets (or the same individual facing different marginal tax rates at different times). This is a particularly effective method of reducing tax liabilities within a family; but differential tax rates may also induce transactions among individuals in different brackets which substantially reduce the aggregate tax liability; the availability of such opportunities leads to what may be referred to as "tax induced transactions."

(3) Tax arbitrage across income streams facing different tax treatment. Under the current law, long term capital gains are taxed at lower rates than are other forms of income from capital. This provides an inducement to "convert" the returns to capital (or to labor) into long-term capital gains. Similarly, special treatment is afforded to the return to capital in the form of housing, pensions, IRAs, etc.

Many tax avoidance devices involve a combination of these three. IRA accounts can be thought of as postponing tax liabilities until retirement; in effect, the interest earned on the IRA account is tax exempt. ${ }^{5}$ On the other hand, if the individual faces a lower tax rate at retirement than at the time he earns his income, then the IRA can be viewed as tax arbitrage between different rates. ${ }^{6} \mathrm{Fi}$ nally, if the individual can borrow to deposit funds in the IRA, and interest is tax deductible, then the IRA is a tax arbitrage between two forms of capital, one of which is not taxed, and the other of which is (tax deductible).?

Investing in assets yielding capital gains involves a tax postponement, since taxes are paid only upon realization. Borrowing to invest in assets yielding capital gains involves a tax arbitrage: the interest is deductible at ordinary rates, the gain is taxed at favorable capital gains rates.

The tax savings from accelerated depreciation with recapture result from postponement. Without recapture, there 
is the additional gain from the favorable treatment of capital gains.

If depreciation allowances corresponded to true economic depreciation, and capital gains were taxed on an accrual basis at full rates, then there would be no tax advantages (or tax induced distortions) from full expensing of maintenance expenses. If capital gains are taxed only upon realization, then full expensing of maintenance expenses (defined as those expenditures required to maintain the value of the property) with depreciation which is rule based (i.e. not directly related to the change in the value of the property) has a tax advantage: while the expenses are currently deductible, the increase in the value (over what it otherwise would be) is only taxable upon realization; there is a gain from postponement; if that gain is taxed at favorable rates, there is a further gain from arbitraging across rates.

Children's trusts involve tax arbitrage across units facing different marginal tax rates. ${ }^{8}$ The trusts are often set up so that their tax year does not coincide with that of the child's; this enables a postponement of the tax liability by almost a year.

The tax advantages that deep discounted bonds previously had arose more from the tax arbitrage across individuals facing different rates and from the tax arbitrage from the differences in the treatment of capital gains and interest income than from the pure postponement effect.

Tax reduction schemes which take advantage of the differences between accrual and cash accounting are, in effect, taking advantage of the gains from tax postponement.

Note that the availability of these different tax reduction-tax avoidance opportunities depends on different aspects of the tax system: tax arbitrage across individuals depends on the progressivity of the tax system, or more accurately, on the fact that marginal tax rates increase with income. ${ }^{9}$ Many of the intra-family tax avoidance schemes entail capital transfers; if capital were not taxed, it would be much more difficult to engage in these tax avoidance schemes.

The possibility of postponement is a concomitant of a tax on a cash basis. ${ }^{10}$ The effect of postponement is often to eliminate (part of) the tax on interest income. Thus, in a flat rate consumption tax, timing is not of importance. ${ }^{11}$

The possibilities of tax arbitrage across different levels of income arise out of the attempts to use the tax system to encourage particular kinds of activities (risky ventures, via capital gains; savings for retirement, via pensions and IRAs).

\section{Some Basic Methods of Tax Avoidance}

So potent are the opportunities for tax avoidance within our current tax structure that, under the hypothesis that capital markets are perfect (zero transactions costs, no restrictions on borrowing or short sales, for every security there is a linear combination of other securities which yields an identical return), individuals could risklessly eliminate all taxes on capital, and indeed, with a little additional effort, they may be able to eliminate their tax liabilities altogether. There is not just one way, but a multiplicity of ways by which taxes can be avoided. Let me briefly describe four modifications of what are, in fact, familiar tax avoidance schemes. The modificationsıarise because, under my assumptions of a perfect capital market, I need not concern myself about transactions costs; I assume that individuals can borrow against collateralizable assets; if the probability of default is zero, they pay the safe interest rate; if not, they will have to pay a higher interest rate, but the interest rate will depend simply on the collateral available to cover the debt in the event of a default. We also assume that all securities can be sold short, and that there are no transactions costs involved in doing so. ${ }^{12}$

Consider first how an individual would have allocated his portfolio over his life in the absence of taxes. (For our purposes, it makes no difference whether the individual has chosen his portfolio to maximize his lifetime expected utility or not.) We construct tax avoidance strategies which leave the individual's consumption and bequests in each state of nature and at each date unchanged (and correspondingly, raise no revenue); the individual 
faces no more (or less) risk than he faced in the original situation. The tax has no real effects on the economy. For simplicity, we assume a given marginal tax rate; thus none of the procedures we describe are based on taking advantage of the opportunities for tax avoidance afforded by different individuals facing different tax rates.

Method 1. Postponement of capital gains. The first method is a modification of the familiar technique of postponing the realization of capital gains, which gives rise to the locked-in effect. It is based on two aspects of the tax code: capital gains are taxed only upon realization, and there is a step up in basis at death. The usual discussions err, however, in not taking into account the fact that the riskiness of an individual's portfolio (and his consumption stream) will change if an individual holds on to an asset longer than he otherwise would simply to avoid taxes. To avoid taxes and any change in the pattern of risk bearing or consumption, the individual sells short a perfectly correlated security (or a set of securities, the returns to which are perfectly correlated with his original securities), at precisely the same moment that he would have, in the absence of taxation, sold the given security. The individual's (net) portfolio positions and income flows are then identical to what they would have otherwise been; but because no capital gain has been realized, no capital gain tax liability has been incurred. It is thus apparent how an individual can risklessly avoid paying capital gains taxes.

But he can do still better for himself. Assume that at any date, the individual buys a security and sells a perfectly correlated (set of) security (securities) short. Again, the individual's net portfolio position is unchanged. At the end of the year, one asset will have increased in value, the other decreased; the individual sells the latter, using the loss to offset other income. At the same time, the individual finds some other security (or linear combination of securities) which is perfectly (positively or negatively) correlated, and takes an offsetting position in that security. Thus, again, the individual has been able to avoid all risk (since throughout, his net position in the set of perfectly correlated securities remains zero). But now he has succeeded in obtaining losses, which he can use to offset against other income. $^{13}$

When the individual dies, his heirs close out his positions; with the step up in basis, no tax liabilities become due.

Two objections to this method that are commonly raised are that it ignores the consequences of limitations on loss offsets and wash sales. These are important questions, to which I shall return later.

Method 2. Arbitraging between shortterm and long-term capital gains rates. The previous method of tax avoidance took advantage of the fact that capital gains are only taxed upon realization; it did not take advantage of the lower rates which are afforded capital gains. The second method does. But while optimal portfolio strategies in the previous method exhibited the "locked-in effect," with this method they do not.

Individuals again purchase and sell short two perfectly correlated securities, so that the net position in the two assets together remains zero; no risk has been incurred. ${ }^{14}$ Just before the end of the minimum holding period required for eligibility for long term treatment, the individual will have made a capital gain on one, a capital loss on the other; he realizes the capital loss, then the next moment (when the security becomes eligible for long term treatment) he realizes the capital gain. If the change in price is $p(t$ $+1)-p(t)$, and long term capital gains are taxed at 40 percent of full rates $(\tau)$, then this tax arbitrage generates a tax saving of

$$
.6 \tau[p(t+1)-p(t)]
$$

The major objection to this method is that it ignores the special provisions by which long-term gains are used to offset shortterm losses. This objection can be overcome, if there are methods by which ordinary income (losses) can be converted into (short-term) capital gains. ${ }^{15}$ There are several methods by which his can be done. For instance, in the options market, some of the capital gains that one attains may be an implicit interest return; that is, one 
can (in principle, in the absence of transactions costs) engage in a set of transactions which involves borrowing and buying options, which is perfectly riskless, but which generates an interest deduction and a short-term capital gain. One can do this to the point that not only are all capital gains offset, but all capital income, and a limited amount of wage income (the limitation of interest deductibility plus the limitation on loss offsets).

Method 3. Indebtedness. The third method takes advantage of the differential treatment afforded long-term capital gains and interest. From an economic point of view, interest and capital gains are simply two alternative forms of return on capital; there would be no reason to differentiate among them. (Indeed, what appears to be a capital gain depends on the choice of a numeraire; though money seems, for many purposes, a natural numeraire, it has increasingly been recognized that for purposes of taxation "consumption" provides a better numeraire; ${ }^{16}$ this is what has given rise to the strong support for indexing the tax system.) Assume that there were no uncertainty about changes in the price of gold. An exhaustible natural resource like gold should have its price rise at the rate of interest. All of the returns, however, are realized in the form of capital gains. If an individual borrows to purchase gold, then his interest would be deductible against ordinary income, his capital gains taxed at favorable rates. With a perfect capital market, there would be no reason that the bank would not lend to the individual: he could simply put up the gold as collateral, and there would thus be no risk to either party.

Actually, to take advantage of this method, long-term capital gains need not even be taxed at lower rates: the individual would gain simply from the postponement effect. And if there is a step up of basis upon death, then the gains from this method are all the greater.

To implement this method, there need not exist a perfectly safe asset; all that is required is that there exists an asset (or a linear combination of assets) which yield a strictly positive return in all states of nature, and that one can issue an option to divest oneself of all the risk associated with returns in excess of the minimum return.

In some sense, this method can be viewed as a special case of Method 1. borrowing is nothing more than selling short a safe bond.

Method 4. Rollovers. This method takes advantage of the arbitrariness of the unit of time over which taxes are levied. It does not, however, require that there be differential tax rates on long-term and shortterm capital gains. As in Methods 1 and 2 , the individual purchases a security and sells short a perfectly correlated security (linear combination of securities), so that he incurs no risk. But now, on December 31 , on one part of his position he will have a capital gain, on the other part a capital loss. He realizes his loss; on January 1, he realizes his gain. The next year, of course, he must engage in similar transactions to a greater extent, not only to wipe out other forms of capital income, but also to eliminate the January 1 capital gain. Though the 1981 Act eliminated some of the easy opportunities for these tax arbitrage activities, it by no means closed all of them.

This list of tax avoidance procedures is not meant to be exhaustive. The incentives for engaging in these activities are sufficiently great that even fairly large transaction costs should not have deterred them. For most of the methods, no capital is required: the individual simply engages in two offsetting actions. Where loans are required, the banks should be willing to provide them, since there are always offsetting assets; indeed, as we have emphasized, these activities are really tax arbitrage activities: the individual needs to undertake no additional risk, so the terms at which banks should be willing to lend to the individual should be the same as they were willing to lend in the absence of taxation.

\section{Limits to Tax Avoidance}

I am not an empirical economist; but there are certain conclusions that one can make about the so called real world without a detailed econometric study. One such conclusion is that individuals do pay taxes, and that indeed, many individuals seem to be paying taxes on their capital in- 
come. There are four possible conclusions one can reach from this empirical observation:

(a) I erred in proving my theorems: the conclusions do not follow from the assumptions.

(b) I erred in failing to take into account certain detailed provisions of the tax code.

(c) I erred in assuming a perfect capital market.

(d) I erred in ascribing more astuteness (understanding of the tax code and the economy) to the taxpayer than he has.

In a talk like this, you will simply have to take my word that the error does not lie in (a). ${ }^{17}$

In my analysis of the tax code, I have kept to the standard textbook formulation. To criticize (b) then is to suggest that the effects of the tax system depend critically on provisions which these treatments have ignored. Among the special provisions, for instance, are those which restrict wash sales, the limitations on the deductibility of losses, and the limitations on the deductibility of interest.

If, however, capital markets were perfect, then these provisions would not be very restrictive. Consider, for instance, the restrictions on wash sales, the purpose of which is to ensure that an individual does not sell and then buy back the security, the only purpose of the transaction being to gain some tax advantage. In a perfect capital market, however, no security is unique: there are many securities (or linear combinations of securities) which yield the identical pattern of returns. Thus, to maintain a riskless position, the individual does not have to buy and sell the same security. Since what is relevant is the individual's subjective judgements concerning the patterns of returns, ascertaining whether the individual has engaged in a riskless arbitrage is a virtual impossibility; and the administrative burdens of attempting to do so, even if subjective probabilities could be ascertained from previous returns, would provide a nightmare of the courts, though possibly a boon to litigation-minded econometricians.

Part of the problem undoubtedly lies in the third assumption: that of a perfect capital market. ${ }^{18}$ As an aside, I find it re- markable how almost a whole sub-discipline has developed, analyzing the behavior of financial markets, attempting to test with sophisticated econometric techniques whether capital markets work perfectly and whether individuals "rationally" allocate their portfolios, which at the same time ignores tax considerations. Ignoring taxes is not ignoring something which should be viewed as leading to a third order refinement of the theory: with wealthy individuals in recent history facing nominal tax rates of 50 percent, 70 percent, or more, the tax effects are first order effects, and any test of any attribute of financial markets which ignores them needs, at best, to be treated with skepticism. Indeed, there is available a simple test of the perfect capital model: do individuals pay taxes, or pay taxes on their capital income?

Moreover, the fact that individuals do not even take full advantage of the limitations on interest deductibility provides further evidence that the perfect capital market/astute investor model is inappropriate. ${ }^{19}$ Whether this is because of capital market imperfections, or because of lack of astuteness on the part of taxpayers, is difficult to ascertain. ${ }^{20}$ Probably both play an important role. In either case, however, the consequences of tax changes may be markedly different from those that would be predicted by the conventional economist's model assuming perfect capital markets and "rational" tax avoiding firms and consumers. ${ }^{21}$ As an example, with imperfect capital markets, an increase in the corporate tax rate might have a deleterious effect on firms' investment because of a reduction in the internal funds available for investment; a perfect market marginal analysis might suggest (with true economic depreciation, and interest deductibility) no effect on investments, since returns and costs of capital are reduced proportionally. (See Stiglitz $[1973,1976]$.)

\section{Tax Avoidance and General Equilibrium Analysis}

One of the important lessons to emerge from the analysis of taxes during the past decade is that one cannot analyze the ef- 
fects of a single tax in isolation from other taxes; for instance, the effects of the corporate income tax depend on the structure of the individual income tax (including its provisions for the taxation of capital gains [Stiglitz, 1973]).

Similarly, the effects of a tax structure cannot be analyzed by looking at its effects on a single individual. This is particularly true of the analysis of tax avoidance. Transactions which reduce one individual's tax liability may increase the tax liability of others. The terms of the transaction will reflect this. Thus, looking at the first individual's tax savings may give a wrong impression both concerning the total cost to the government of the tax avoidance activity and the incidence of the benefits from tax avoidance.

This general principle has been recognized for a long time. If all individuals faced the same marginal tax bracket, then exempting state and local bond interest would simply reduce the rate of return on these bonds to the point where it equalled the after-tax return of taxed bonds (of equal risk). The individual would be no better off than he would have been if he had not bought the tax exempt bonds. The benefits all accrue to the communities issuing them. ${ }^{22}$

How does this general equilibrium perspective alter our analysis of the previous section? Two questions need to be posed.

Consistency of tax avoidance activities. First, if all individuals attempted to pursue the policies indicated, would they be able to avoid taxes?

At first blush, the answer seems to be no: assume two individuals $A$ and $B$ were pursuing tax avoidance method \#2. Assume securities $\mathrm{x}$ and $\mathrm{y}$ are perfectly correlated. Individual $A$ buys a share of $\mathbf{x}$ and sells short a share of $y$; individual $B$ buys a share of $y$ and sells short a share of $x$. Their actions are offsetting: the net demand for shares in $x$ and $y$ are unaffected. At the end of six months assume the price of $x$ (and $y$ ) has in fact decreased. Thus A sells x, and B sells y: their actions are not offsetting. It appears as if markets do not clear. But this ignores the fact that both $A$ and $B$ will want to cover their exposed position for the moment from just before six months to just after six months: A will wish to buy $y$ and $B$ will wish to buy $x$; hence the net demand remains zero.

A similar analysis applies for the rollover method. Now, on December 31, A sells $\mathrm{x}$ and buys $\mathrm{y}$, while $\mathrm{B}$ sells $\mathrm{y}$ and buys $\mathrm{x}$. These methods work even if the "asset" purchased is a contract on the futures market. In such markets, whenever one individual takes a position, another individual takes the opposite position. Thus, if A sells B a contract for future delivery of wheat at a fixed price, when the price of wheat goes up, A is worse off, B is better off. Assume A sells B a contract for wheat, and B sells A a contract for a perfectly correlated commodity, which we shall refer to as Commodity Z. The positions are offsetting so neither individual is bearing any risk. Assume just before the end of six months the price of wheat has risen. A sells his contract for delivery of wheat to $\mathrm{C}$, realizing a short-term capital loss; at the same time he buys from $\mathrm{C}$ a contract for delivery of commodity Z; similarly $\mathrm{C}$ buys from $\mathrm{B}$ a contract for the delivery of $Z$, and sells a contract for the delivery of wheat. At the end, A, B, and C remain perfectly hedged. Then, just after six months has passed, all positions are closed out: A realizes a long-term gain on his commodity $\mathrm{Z}$ contract, $\mathrm{B}$ a long-term gain on his wheat contract, and $C$ realizes small, offsetting gains and losses.

Note that this tax arbitrage possibility was not eliminated by provisions for constructive realization on December 31 . These were aimed at our fourth method of tax avoidance, recording losses in one year and gains the next.

Note that tax avoidance schemes based on borrowing would not be effective in an economy in which all individuals faced the same marginal tax rate: any tax savings from an interest deduction by one individual would give rise to an offsetting tax liability by another.

Though the general equilibrium perspective alters one's views concerning the tax savings which can be achieved by 
purely financial arbitrage activities, at least in a world in which all individuals face the same tax rate, the basic tax avoidance principles we described earlier can be used to reduce, and possibly eliminate, taxes on the return to real capital assets. Thus, the present discounted value of tax liabilities are reduced as a result of postponing the realization of gains and taking losses as soon as possible ${ }^{23}$ and they are reduced by holding on to assets which have increased in value at least to the time at which they are eligible for long-term treatment.

\section{The Relative Importance of Different Tax Avoidance Devices}

We have thus shown that some of the tax avoidance strategies described earlier are effective, even in a world in which all individuals faced the same tax rate, and even when the tax counsequences for all individuals were appropriately taken into account. But the aggregate tax savings associated with various transactions may be far different from what appear ${ }^{24}$ to be the tax savings to one individual. As a result, the relative importance of different tax avoidance schemes may look quite different from a general equilibrium ${ }^{25}$ perspective than from a partial equilibrium perspective. In particular, many of the tax savings which appear as arising from postponement are really tax savings which arise from arbitraging across rates. We have noted one example earlier: the real tax savings (at least in a perfect capital market) from IRA accounts arise not from the postponement of taxes, but from arbitraging between the tax deductibility of interest and the non-taxability of interest accruing in IRA accounts. ${ }^{26}$

Installment purchases. As another example consider the tax consequences of a delay in the "official" transfer of the ownership of an asset (for tax purposes). It appears as if there has been a gain from postponement. Assume the two individuals involved in the transaction are in the same tax bracket; $A$ is selling the asset to B. Assume, moreover, that A wishes to receive the cash today. If the sale was completed today, A would incur a tax liability of, say, tg, where $g$ was the capital gain on the asset. Assume, instead, that $B$ lends him the money at a zero interest rate $^{27}$; A effectively turns over control of the asset, but the sale is not officially completed until the next period. Then the only implications for either party is that the present discounted value of the tax liability on the capital gains has been reduced. Since capital gains taxes are paid only upon realization, there is a general equilibrium tax savings from postponing realization.

But if $A$ and $B$ are in different tax brackets, the tax savings may be far larger: If the gain is "recognized" today, A has, after tax, $\left(1+g-g_{A}\right)$, where 1 is his basis; and if he invests this, at the after tax return of $r^{\prime}{ }_{A}$, he will have $(1+$ $\left.g-g t_{A}\right)\left(1+r^{\prime}{ }_{A}\right)$. On the other hand, if the trade is not "consummated" until next period, $B$ will have $(1+g)\left(1+r^{\prime}{ }_{B}\right)$. Assume $B$ turns this over to $A$. $A$ will then have, after tax,

$(1+g)\left(1+r^{\prime}{ }_{B}\right)\left(1-t_{A}\right)+t_{A}$,

a gain of

$\left(r^{\prime}{ }_{B}-r_{A}^{\prime}\right)\left(1+g\left(1-t_{A}\right)\right)+t_{A} r_{B}^{\prime} ;$

the first term represents the gain from tax arbitrage across individuals; the second terms represents the gain from postponement. As the limiting case, assume B has a zero marginal tax bracket, and $A$ is in the 50 percent tax bracket, with capital gains taxed at 20 percent. Then the tax savings is $.5 r(1+.8 g)+.2 r$; the tax savings are largely due to arbitraging across individuals.

Early recognition of gains. In the example we have just described, we have shown how it may pay to delay the "official" transfer by ownership (and thus the recognition of a capital gain). But this is not always the case. With depreciable assets, there is a step up in basis upon the transfer of ownership, and the tax advantages of this may well outweigh the disadvantages of paying the capital gains tax. 
Take, as an example, a machine which will last for one more year. It was expected to produce an output of $\$ 1$; at a 10 percent discount rate, its current value is approximately $\$ .9$. Assume now that the (net) output that it is expected to produce doubled; this would imply that its market price would double; the owner would have a $\$ .9$ capital gain. But note that we will tax the extra income as it accrues. To tax the capital gain, representing the expectation of future income and to tax the extra future income seems to be taxing the same extra income twice, and this seems unfair. But, if we have true economic depreciation, there is not any real "double" taxation; the new owner will have higher depreciation allowances reflecting the higher capital value. With true economic depreciation, full taxation of (accrued) capital gains would be required in this situation to avoid distortions within an income tax. With a flat rate tax, the difference between doing this, and simply taxing the income as it accrued is the tax on the (implicit) interest income. In our example there will be a capital gain of $1 /$ $1+\mathrm{r}=.9$, in the absence of taxation; with taxation, but true economic depreciation, the present discounted value of this increase is unchanged. ${ }^{28}$ Hence, the increase in tax liabilities is $t /[1+r]$ this period; next period net income is $1-\mathrm{de}-$ preciation $=1-1 /[1+\mathrm{r}]=\mathrm{r} /[1+\mathrm{r}]$ and the tax next period is thus $\operatorname{tr} /[1+r]$. The present discounted value of tax payments, using the discount rate, $r^{*}$, is just $\mathrm{t}\left[(1 / 1+\mathrm{r})+\left(\mathrm{r} /(1+\mathrm{r})\left(1+\mathrm{r}^{*}\right)\right]=\mathrm{t}[1+(\mathrm{r} /\right.$ $\left.\left.1+\mathrm{r}^{*}\right)\right] / 1+\mathrm{r}$.

If there had been no tax on capital gain, but no concurrent increase in the depreciation allowance, the increase in tax liability (as a result of the increased productivity of the asset), next period is just $t$. Thus, the difference in the present discounted value of tax liabilities is just $t$ / $(1+r)+[t /(1+r)][1-(1 /(1+r)]-t /$ $\left(1+r^{*}\right)=\operatorname{tr} /(1+r)^{2}+t\left(r^{*}-r\right) /(1+$ $\left.\mathbf{r}^{*}\right)(1+\mathbf{r})$.

On the other hand, if the asset were sold, by individual $A$ to individual $B$, with true economic depreciation, the total present discounted value of the difference in tax liabilities (between what it would have been without the realization of the capital gain and the corresponding step up in basis and with it) is ${ }^{29}$

$$
\begin{aligned}
& t_{A} / 1+r+\left(t_{B} / 1+r_{B}^{*}\right)[1-(1 / 1+r)] \\
& \quad-t_{A} / 1+r_{A}^{*}=\left[t_{A}\left(r^{*}-r\right)\left(1+r_{B}^{*}\right)+t_{B} r\right. \\
& \left.\left(1+r_{A}^{*}\right)\right] /(1+r)\left(1+r_{A}^{*}\right)\left(1+r_{B}^{*}\right) .
\end{aligned}
$$

Thus, with a flat rate tax, with $r=r^{*}$, with full taxation of capital gains, and with true economic depreciation, it would always pay to postpone the realization of the gain. But if $r_{A}^{*}=\left(1-t_{A}\right) r$, then early realization may be desirable. All of this changes dramatically, however, when there is not true economic depreciation and when capital gains are taxed at favorable rates. Consider first the consequences of taxing capital gains at favorable rates, say .4 of ordinary rates. Then the net change in aggregate tax liabilities from the transfer is $.4 t_{A} / 1+r+\left(t_{B} / 1+r^{*}{ }_{B}\right)[1-$ $1 / 1+r]-t_{A} / 1+r^{*}{ }_{A}=\left[-t_{A} z+r_{B} / 1+\right.$ $\mathrm{r}] / 1+\mathrm{r}_{\mathrm{B}}^{*}, \mathrm{z}=\left(1+\mathrm{r}_{\mathrm{B}}^{*}\right) /\left(1+\mathrm{r}_{\mathrm{A}}^{*}\right)-.4(1$ $\left.+\mathrm{r}_{\mathrm{B}}^{*}\right) /(1+\mathrm{r})=.6$ if $\mathrm{r}_{\mathrm{B}}^{*}=\mathrm{r}_{\mathrm{A}}^{*}=\mathrm{r}$. Thus, for short lived assets (low $r$ ) or highly taxed individuals $\left(\right.$ high $t_{A}$ ), it pays to realize the capital gain early. ${ }^{30,31}$

The tax consequences of recognizing a capital gain are somewhat different if there is accelerated depreciation. Consider a two period asset, whose return at each date unexpectedly increases by a dollar. With straight line depreciation the increment in value is given by the solution to

$V=\left(1-t_{B}\right) \delta+t_{B} \delta V / 2$

where

$\delta=1 / 1+r^{*}{ }_{B}+1 /\left(1+r^{*}{ }_{B}\right)^{2}$

Hence

$\mathrm{V}=\left(1-\mathrm{t}_{\mathrm{B}}\right) \delta /\left[1-\mathrm{t}_{\mathrm{B}} \delta / 2\right]$

Hence the change in tax liability from transferring ownership is (using B's discount rate) 


$$
\left(.4 \mathrm{t}_{\mathrm{A}}-.5 \delta \mathrm{t}_{\mathrm{B}}\right) \mathrm{V}+\left(\mathrm{t}_{\mathrm{B}}-\mathrm{t}_{\mathrm{A}}\right) \delta \text {. }
$$

The accelerated depreciation presumably increases the value of an asset. Notice, however, that with a flat rate tax, with no favorable treatment of capital gains, the magnitude of the tax change from transferring ownership is relatively small, Thus, with a flat rate tax, the distortions associated with the failure to tax capital gains on depreciable assets upon accrual may be relatively small.

Our general equilibrium analysis of the tax consequences of the realization of capital gains has thus uncovered a fundamental error in the standard partial equilibrium treatment. The gains from the step-up in basis have to be contrasted with the losses from the early recognition of a gain: though with true economic depreciation and full taxation of capital gains, it remains true that early recognition is undesirable, with favorable treatment of capital gains and with depreciation that is faster than true economic depreciation, early recognition may well be desirable; the gains become particularly significant, however, when individuals are in markedly different tax brackets.

Ownership of "capital gain assets." Similarly, the tax structure potentially has important implications for the pattern of ownership of assets. Assume, for instance, that A owns an asset which naturally yields its return in the form of capital gains (like gold). Assume that the real rate of capital gain is $g$. If A lends B the money to buy the asset, charging an interest rate equal to $\mathrm{r} *$, where

$\mathrm{r} *\left(1-\mathrm{t}_{\mathrm{A}}\right)=\mathrm{g}\left(1-.4 \mathrm{t}_{\mathrm{A}}\right)$

then $A$ is indifferent: $A$ has received the same after tax return. But B's net income is

$$
\begin{aligned}
1 & +g\left(1-.4 t_{B}\right)-\left(1+r *\left(1-t_{B}\right)\right) \\
& =g\left[\left(1-.4 t_{B}\right)-\left(1-t_{B}\right)\right. \\
& \left.\left(1-.4 t_{A}\right) /\left(1-t_{A}\right)\right] \\
& =.6 g\left(t_{B}-t_{A}\right) / 1-t_{A}>0
\end{aligned}
$$

if $B$ faces a higher tax rate than $A$. This suggests that all of the capital gain yielding assets should be owned by individuals in the high tax brackets. (High tax bracket individuals should engage in this kind of arbitrage until either there are no more such opportunities (and additional opportunities cannot easily be created) or until tax brackets are equalized.)

These calculations suggest that much of the gain from tax avoidance activities under our present tax structure arise from arbitraging across rates, rather than from postponement. Indeed, there is some question about the significance to be attached to the postponement effect. Real rates of interest on government securities ${ }^{32}$ have, from 1950 to 1984 , averaged less than .75 percent. Thus the loss to the government from a tax which is postponed for five or ten or even twenty years is relatively small. Individuals' gains may be much higher: they face higher real interest rates. ${ }^{33}$ Because of limitations on collateralizable assets, the government may be in a better position to serve as a "lender" (through the tax system) than are private lenders.

(With a progressive tax system, the government may not be in an advantageous position relative to a private lender. While limited liability limits in general, what a private lender can get back, a private lender can require the owner of a firm to sign a personal note guaranteeing part or all of a loan. The government cannot, and individuals thus can design contracts under which losses accrue to those in high marginal tax rates, gains to those in low marginal tax rates, in effect yielding the government a negative return on its loan.)

To the extent that the government can devise tax systems which allow individuals discretion in the timing of their tax liabilities, the government may be improving the efficiency of the capital market and this in turn will have a beneficial effect on the economy. But though there may be some beneficial effects associated with "postponement" many of the tax avoidance activities have a deleterious effect.

Real resource allocation effects. Most of this paper has focused on how paper 
transactions can, without cost to society, ${ }^{34}$ enable the reduction in tax liabilities. In the presence of a perfect capital market, presumably all tax liabilities could be eliminated. But we do not have a "perfect" capital market, and all tax liabilities are not, therefore, eliminated simply by means of "paper" transactions. To reduce tax liabilities distorting actions are resorted to. Some of these are closely linked to the very reason that capital markets are not perfect.

Elsewhere, I have argued why imperfections (and, in particular, asymmetries) of information result in the capital market being fundamentally different from how it is envisaged in the traditional neoclassical paradigm. ${ }^{35}$ In that model, ownership makes no difference: the manager simply maximizes the market value of the firm. But with imperfect information (or incomplete markets), ownership is of importance. And ownership entails having the claim on residual income (and having other residual rights not specified in a contractual arrangement). Thus, in our earlier discussion, we noted that there was an incentive to delay the recognition of a capital gain, by delaying the completion of a transaction, i.e. delaying the turning over of all residual claims with respect to income and other rights.

Similarly, we noted there was an incentive to have higher income individuals receiving income in the form of capital gains, lower income individuals in the form of interest; while the latter are usually associated with debt, the former are associated with "ownership"36; thus, our tax system encourages the perpetuation of control of productive assets by the wealthy.

These are, by no means, the only real distortions associated with our tax system: since there are some sectors where it seems easier to convert ordinary income into capital gains (real estate, in particular), investments in these sectors are encouraged, since they increase the opportunities for tax avoidance.

\section{Tax Reform}

This analysis of tax avoidance behavior has some striking implications for tax re- form. Many of the tax avoidance schemes lose their force (within a general equilibrium context) with a flat rate tax (or with greatly reduced differences in marginal tax rates).

With a flat rate income tax, for instance, all interest received could be made tax deductible (with interest payments not tax deductible). In a closed economy, the only net interest payments would be from the government. Given the current tax deductibility of state and local interest payments, the only effect would be to decrease the interest rate the federal government would have to pay (it would be as if the government collected the tax on its interest payments at source). ${ }^{37}$ (In an open economy, the effect of making interest income non-taxable would depend on the treatment of payments to and from foreign sources.)

Similarly, as we have noted, some of the central problems of capital gains taxation are reduced with a flat rate tax.

We have emphasized so far the important role that differences in marginal tax rates play in tax avoidance under the income tax. Similar problems might well arise in the consumption tax. Consider, for instance, the Blueprints proposal to have registered and unregistered assets. Assume A is in a higher tax bracket than $B$. Assume A and B swap registered for unregistered assets, so that it appears as if A's consumption has decreased and B's consumption has increased. Then current tax liabilities would have reduced (for A and $B$ together) by $t_{A}-t_{B}$. To avoid risk, $A$ and $B$ sign contracts promising to swap back again next year. It will then appear as if A's consumption has, at that date increased, and B's consumption has decreased. Whether the present discounted value of tax liabilities will have increased or decreased (in the aggregate) as a result of this tax swap depends on the relative valuation of the assets at the two dates. If the values increase by the market rate of interest, there will be no change in the present discounted value of aggregate tax liabilities. But if the values increase less than the rate of interest, then such a swap reduces the aggregate tax liabilities, and if the values increase by more than the 
rate of interest, then the reverse swap would reduce the aggregate tax liabilities. One of the main arguments in favor of the consumption tax, that it would avoid the difficult and arbitrary valuation problems which are pervasive under the income tax, seems less persuasive in the context of a consumption tax which does not have a flat rate. And such tax avoidance activities may have quite similar distortionary effects to the kinds of tax avoidance activities currently observed under the income tax.

\section{Conclusions}

We have outlined in this paper a general set of principles for tax avoidance; most of at least the common tax avoidance schemes can be reinterpreted as making use of one or more of these principles.

In a perfect capital market, these principles of tax avoidance are so powerful as to enable the astute taxpayer to eliminate all taxation on capital income, and possibly all taxation on wage income as well. The fact that the tax system raises revenue is thus a tribute to the lack of astuteness of the taxpayer and/or the lack of perfection of the capital market.

This in turn has an important implication: one should treat with some skepticism models which attempt to analyze the effects of taxation assuming rational, maximizing taxpayers working within a perfect capital market.

Some (perhaps most) of the imperfections of the capital market are attributable to imperfections (including asymmetries) of information. In economies with imperfect information ownership/control is important; many of the tax avoidance devices necessitate altering patterns of ownership, and this may have important implications for real resource allocation.

A full analysis of tax avoidance cannot be conducted within a partial equilibrium model; when one individual reduces a tax liability through some transaction, that transaction may at the same time increase the tax liability incurred by another. In that case, the terms at which the transaction are conducted will reflect this "shifting" of tax liabilities. If the two individuals are in the same tax bracket, no real tax avoidance may have occurred. Such is the case when an individual borrows from another; while the interest is deductible by one, it is taxable to the other. We have delineated those tax avoidance schemes which do indeed reduces the aggregate tax liabilities of all those who participate in them.

We have noted, in particular, that much of the "general equilibrium" gain from tax avoidance arises from differences in tax rates, both across individuals and across classes of income (rather than from "postponement"). If this is true, then reforms aimed at reducing the differences in marginal tax rates may be effective in reducing tax avoidance; there may be significant gains to be had from going to a flat rate tax, whether of the income or consumption variety.

\section{FOOTNOTES}

'Financial support from the National Science Foundation is gratefully acknowledged.

${ }^{2} I$ focus on the individual income tax, and do not discuss the role of the corporation tax in tax avoidance, or the methods by which corporate tax liabili. ties may be reduced.

In terms of the Cordes-Galper classification of tax shelters, the tax avoidance schemes on which I focus are pure arbitrage schemes ("pure tax shelters") as opposed to "tax-preferred activities" such as gas and oil.

In my analysis, I do not discuss, moreover, the economic, political, or social arguments behind those provisions of the tax code which give rise to tax avoidance opportunities. My concern is rather to describe the consequences of these provisions. To the extent that these tax avoidance activities run counter to the intent of these provisions, these consequences clearly have to be borne in mind in evaluating their desirability.

${ }^{3} \mathrm{~A}$ fuller discussion of these tax avoidance principles is contained in Stiglitz, [1986] Chapter 24, "A Student's Guide to Tax Avoidance".

${ }^{4}$ Unless, of course, the tax liability is increased as a result of postponement. We shall note instances of this below.

"That is, if the individual's marginal tax rate at the date he earned the income and at retirement were the same, $\tau$, then, if he paid the tax at the time he earned the income, but if interest income were tax exempt, he would have at retirement, $T$ years later, $(1-\tau) e^{-r T}$, whereas if he used an IRA account, at retirement he would have, before taxes $\mathrm{e}^{-\mathrm{rT}}$, and after taxes he would have had $(1-\tau) e^{-r T}$, precisely the same amount.

"Though the term "tax avoidance" suggests that individuals are not paying taxes that they "should" this 
is not necessarily the case: even apart from the al. leged beneficial incentive arguments often raised in behalf of special tax provisions by their advocates, there may be equity arguments as well. For instance, lifetime income seems a more equitable tax base than annual income; but provisions for income averaging are inadequate. Hence, "arbitrage" by individuals across different marginal tax rates they face at different times of their lives increases the equity of the tax system.

${ }^{7}$ For a fuller discussion of the incentive and equity effects of IRAs, see Stiglitz, [1986], Chapters 22 and 23.

${ }^{8}$ Though the maximum tax savings from this kind of tax arbitrage is limited. If a wealthy, married couple with four children set up eight trusts, their maximum total tax savings in 1983 was $\$ 90,700$. The minimum income required to achieve this is $\$ 745,400$. Somebody with this income has his average tax rate reduced from $47.9 \%$ to $35.7 \%$.

${ }^{9} \mathrm{~A}$ flat rate tax with an exemption is progressive, in the sense that the average tax rate increases with income.

${ }^{10}$ Though under accrual, there are often opportunities for postponement, taking advantage of particular rules which define when income or expenses are accrued.

${ }^{11}$ Later, we shall show that, at least for some versions of a progressive consumption tax, there may still be tax avoidance possibilities.

${ }^{12} \mathrm{We}$ ignore all the institutional details associated with short sales. If a security costs $p$ and yields a stream of returns of $x(\theta, t)$, in state $\theta$ at date $t$, then if an individual sells the security short, he receives $p$, and must pay out $-x(\theta, t)$ in state $\theta$ at date $t$.

${ }^{13}$ Note that in our perfect capital market world, the individual needs no capital to engage in these transactions.

${ }^{14}$ Again, the individual could buy two perfectly negatively correlated securities; or he could identify two perfectly correlated sets of securities, buying one and selling the other short.

${ }^{15}$ Note that the objective in converting ordinary income losses into short term capital gains is not to gain a direct tax savings - the two are taxed at the same rate; but rather to overcome other limitations within the tax code which might restrict the ability to take advantage of the favorable treatment of long-term capital gains.

${ }^{16}$ Elsewhere, I have argued that the main distortion to our economy from inflation arises from the failure to appropriately index the tax system. See Stiglitz [1981].

${ }^{17}$ For sketches of proofs, see Stiglitz [1983].

"The term "imperfect capital markets" is used to cover a whole host of sins. The imperfections with which we are concerned here need not reflect "irrationalities" of the market. Rather, they may be the consequence of real costs of transactions and imperfect and costly information. Simple transactions costs (i.e., those not associated with imperfect information) probably cannot account for the failure of individuals to take full advantage of the available tax avoidance schemes. Imperfect information can account both for credit rationing and the high costs of raising funds by issuing new equity. See Stiglitz and Weiss [1981, 1983], and Greenwald, Stiglitz, and Weiss [1984].
${ }^{19}$ See Feenberg [1981].

${ }^{20}$ There are many other instances in which taxpayer behavior seems inconsistent with perfect markets with perfectly rational individuals. These include the "dividend paradox" [Stiglitz, 1973], the "inventory valuation paradox," and the "managerial compensation paradox." In each case, the behavior can be "explained" by rational managers dealing with irrational shareholders or by non-maximizing (non-astute) managers. See Stiglitz [1982b, 1985a, 1985b].

${ }^{21}$ Similarly, optimal portfolio behavior with taxes and imperfect capital markets is markedly different from what it would be without taxes and perfect capital markets. See Stiglitz [1983].

${ }^{22}$ Of course, if no restrictions are imposed on communities issuing these bonds, they could engage in tax arbitrage, raising funds by issuing tax exempt bonds and then lending out the money.

${ }^{23}$ In particular, even if there were not favorable treatment of long term capital gains, losses should be recognized in the year in which they occur. Assume there are two perfectly correlated assets, $x$ and $y$, which have decreased in price. If $A$ owns $x$ and $B$ owns $y$, they can achieve a tax savings by swapping on December 31; this leaves unaltered their risk position.

${ }^{24}$ The actual tax savings to the individual may also be quite different from what they appear to be because the terms of the transaction may be markedly different from what they would have been in the absence of taxation.

${ }^{25}$ It should be emphasized that our general equilibrium analysis is still not completely general: we ignore effects on prices and before-tax interest rates. These are crucial for assessing the incidence of tax avoidance schemes such a real estate, and gas and oil investments, as opposed to the pure tax arbitrage schemes. See Stiglitz [1986].

${ }^{26}$ It obviously makes no difference whether individuals are restricted from borrowing to deposit funds in IRA accounts. Individuals simply borrow more for other reasons, leaving them more money available for depositing in their IRA accounts. The only real effects arise if IRA accounts are not collateralizable.

${ }^{27}$ The interest rate charged makes no difference to aggregate tax liabilities, since the tax liability of B is offset by the tax deduction of $A$.

${ }^{28}$ The incremental value, with true economic depreciation, is

$\mathrm{V}=[1-\mathrm{t}(1-\mathrm{V})] / 1+\mathrm{r}(1-\mathrm{t})$

$\mathrm{V}=(1-\mathrm{t}) /[1+\mathrm{r}-\mathrm{rt}-\mathrm{t}]$

$V=(1-t) /[(1+r)(1-t)]$

$=1 / 1+\mathrm{r}$

${ }^{29}$ This calculation discounts each individual's tax liabilities at his own discount rate.

${ }^{30}$ Remember these calculations have nothing to do with the transfer of "money," only with the transfer of ownership claims in the asset.

${ }^{31}$ The critical condition for the desirability of ownership transfer is

$.6 \mathrm{t}_{\mathrm{A}} \geq \mathrm{rt}_{\mathrm{B}} / 1+\mathrm{r}$.

Thus, if $t_{A}=t_{B}$, asset transfer is desirable if $r \leq 1.5$.

${ }^{32}$ Three month Treasury bill rates minus the rate of inflation. 
${ }^{33}$ Presumably, reflecting the greater risk to lending to them. They may also face credit rationing. See Stiglitz and Weiss [1981].

${ }^{34}$ Other than the direct transactions costs.

${ }^{35}$ See, for instance, Stiglitz [1982a and 1985a].

${ }^{36}$ There are some subtle and difficult questions associated with why this is so, and whether it must necessarily be so.

${ }^{37}$ With a flat rate tax, interest rates on state and local bonds would presumably fully reflect the tax exempt status; the only inefficiency associated with the tax deductibility of state and local interest is the incentive that it would provide for excessive capital expenditures.

\section{REFERENCES}

Atkinson, A. and J. E. Stiglitz [1980], Lectures in Public Economics, New York and London: McGrawHill Book Company.

Cordes, J. J. and H. Galper [1985], "Tax Shelter Activity: Lessons From Twenty Years of Evidence," paper presented at a Symposium of the National Tax Association-Tax Institute of America, May 1985.

Feenberg, D., [1981], "Does the Investment Interest Limitation Explain the Existence of Dividends?," Journal of Financial Economics, pp. 265-269.

Greenwald, B., J. E. Stiglitz and A. Weiss, [1984] "Informational Imperfections in the Capital Market and Macroeconomic Fluctuations," American Economic Review, May, Vol. 17, pp. 194-199.

Stiglitz, J. E., [1973], "Taxation, Corporate Financial Policy and the Cost of Capital," Journal of Public Economics, Vol. 2, February, pp. 1-34.
Stiglitz, J. E., [1976], "The Corporation Tax," Journal of Public Economics, April-May, pp. 303-311.

Stiglitz, J. E., [1981], "On the Almost Neutrality of Inflation" in Development in an Inflationary World, eds. M. June Flanders and Assaf Razin, Academic Press.

Stiglitz, J. E., [1982a], "Information and Capital Markets" in Financial Economics: Essays in Honor of Paul Cootner, William Sharpe and Cathryn Cootner eds., (Englewood Cliffs, New Jersey: Prentice Hall).

Stiglitz, J. E., [1982b], "Ownership, Control and Efficient Markets: Some Paradoxes in the Theory of Capital Markets," in Economic Regulation: Essays in Honor of James R. Nelson, Kenneth Boyer and William G. Shepherd eds., (East Lansing, Michigan: Michigan State University Press), pp. 311-341.

Stiglitz, J. E., [1983], "Some Aspects of the Taxation of Capital Gains," Journal of Public Economics, Vol. 21, pp. 257-294.

Stiglitz, J. E., [1985a], "Credit Markets and the Control of Capital," Journal of Money, Credit and Banking, May, Vol. 17, pp. 133-152.

Stiglitz, J. E., [1985b], "Information and Economic Analysis: A Perspective," Economic Journal Supplement, Spring, Vol. 95, pp. 21-42.

Stiglitz, J. E., [1986], Economics of the Public Sector, Norton and Company, New York.

Stiglitz, J. E. and A. Weiss, [1981], "Credit Rationing in Markets with Imperfect Information," American Economic Review, June, Vol. 71, No. 3, pp. 393-410.

Weiss, A. and J. E. Stiglitz, [1983], "Incentive Effects of Termination: Applications to the Credit and Labor Markets," American Economic Review, December, Vol. 73, pp. 912-927. 
Copyright of National Tax Journal is the property of National Tax Association. The copyright in an individual article may be maintained by the author in certain cases. Content may not be copied or emailed to multiple sites or posted to a listserv without the copyright holder's express written permission. However, users may print, download, or email articles for individual use. 